\title{
Statutory compliance in assets disposal practices in the public sector: Evidence from Ghana
}

\begin{tabular}{|c|c|}
\hline $\begin{array}{l}\text { Authors: } \\
\text { Oswald Atiga }{ }^{1} \\
\text { Christopher J. } \\
\text { Joseph D. Nye }\end{array}$ & $\begin{array}{l}\text { Adafula }^{2} \\
\operatorname{adi}^{3}\end{array}$ \\
\hline $\begin{array}{l}\text { Affiliations: } \\
{ }^{1} \text { Department } \\
\text { and Logistics N } \\
\text { Bolgatanga Po } \\
\text { Ghana }\end{array}$ & $\begin{array}{l}\text { of Procurement } \\
\text { Management, } \\
\text { lytechnic, }\end{array}$ \\
\hline $\begin{array}{l}{ }^{2} \text { Department } \\
\text { Auditing, Bolg } \\
\text { Polytechnic, G }\end{array}$ & $\begin{array}{l}\text { of Internal } \\
\text { atanga } \\
\text { hana }\end{array}$ \\
\hline $\begin{array}{l}{ }^{3} \text { Department } \\
\text { Technology an } \\
\text { Management, } \\
\text { Polytechnic, G }\end{array}$ & $\begin{array}{l}\text { f Building } \\
\text { d Estate } \\
\text { Wa } \\
\text { hana }\end{array}$ \\
\hline $\begin{array}{l}\text { Corresponden } \\
\text { Oswald Atiga }\end{array}$ & ce to: \\
\hline $\begin{array}{l}\text { Email: } \\
\text { oswaldatiga@ }\end{array}$ & yahoo.com \\
\hline $\begin{array}{l}\text { Postal addres } \\
\text { PO Box } 767, \text { B } \\
\text { Ghana }\end{array}$ & s: \\
\hline $\begin{array}{l}\text { Dates: } \\
\text { Received: } 26 \mathrm{~A} \\
\text { Accepted: } 14 \\
\text { Published: } 31\end{array}$ & $\begin{array}{l}\text { Aug. } 2014 \\
\text { Dec. } 2014 \\
\text { Mar. } 2015\end{array}$ \\
\hline $\begin{array}{l}\text { How to cite th } \\
\text { Atiga, O., Adaf } \\
\text { Nyeadi, J.D., } 2 \\
\text { compliance in } \\
\text { practices in th } \\
\text { Evidence from } \\
\text { Journal of Tra } \\
\text { Supply Chain I } \\
\text { 9(1), Art. \#158 } \\
\text { http://dx.doi.c } \\
\text { jtscm.v9i1.158 }\end{array}$ & $\begin{array}{l}\text { is article: } \\
\text { ula, C.J. \& } \\
\text { 015, 'Statutory } \\
\text { assets disposal } \\
\text { e public sector: } \\
\text { Ghana', } \\
\text { nsport and } \\
\text { Management } \\
\text {, } 6 \text { pages. } \\
\text { org/10.4102/ }\end{array}$ \\
\hline $\begin{array}{l}\text { Copyright: } \\
\text { C 2015. The A } \\
\text { Licensee: AOS } \\
\text { OpenJournals } \\
\text { licensed unde } \\
\text { Commons Attr } \\
\text { License. }\end{array}$ & $\begin{array}{l}\text { Authors. } \\
\text { IS } \\
\text { This work is } \\
r \text { the Creative } \\
\text { ibution }\end{array}$ \\
\hline Read online: & \\
\hline 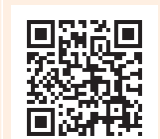 & $\begin{array}{l}\text { Scan this QR } \\
\text { code with your } \\
\text { smart phone or } \\
\text { mobile device } \\
\text { to read online. }\end{array}$ \\
\hline
\end{tabular}

Background: This article examined the unserviceable assets disposal practices of five polytechnics (tertiary educational institutions) in Ghana.

Objectives: The aim was to determine the extent of statutory compliance, and the degree to which value for money was achieved in actual disposal.

Method: A survey was conducted using interviewer-administered questionnaires containing five-point likert scale test items. Descriptive statistics and a one-way analysis of variance (ANOVA) were employed to analyse the data.

Results: The study results showed that a limited number of polytechnics had internal policies to operationalise statutory procurement legislation. Top management demonstrated very clear understanding of procurement legislation whilst senior-level managers displayed mixed levels of understanding. The section of the legislation dealing with disposals and the procedures pertaining thereto is perceived to be difficult to implement and does not promote value for money. Top management's interference in auctions was the toughest challenge in the process, whilst public auction was the predominant method used in assets disposal.

Research limitations: The research was carried out in only five polytechnics. This study could be replicated in other tertiary institutions or in other sectors outside higher education.

\section{Introduction \\ Background}

'Disposal' is the act of derecognising an asset that has reached the end of its useful life when no future economic benefits or service potential is further expected from its use. Assets of such nature must be disposed or boarded off either with the aim of producing some financial returns or decongesting the stores to make way for new items and products. Section 83 of Ghana's Public Procurement Act (Act No. 663 of 2003) clearly empowers heads of procurement entities to dispose of unserviceable goods, plants and equipment and sets out the following criteria:

- transfer to government departments or other public entities, with or without financial adjustment

- sale by public tender to the highest tenderer, subject to reserve price

- sale by public auction, subject to reserve price

- destruction, dumping or burying as appropriate (Ghana Government 2003).

Irrespective of the position of Ghana's legislation on stores disposal, there seems to be a gap between actual disposal practices of government agencies and legislation. Weakness in or the absence of institutional policies in the public sector have been cited as some of the factors that aid the perpetuation of corruption by public officers (Hutter \& Shar 2000). The World Bank, Transparency International and other anti-corruption agencies across the globe are unanimous on this diagnosis. Advocates of good governance practices worldwide have prescribed and campaigned for the use of legislation to mitigate corruption (Persson, Rothstein \& Teorell 2010). The deterrent effect of legislation often acts as a disincentive, especially when the prescribed punishment is draconian (Alberto \& Tella 1997; Coldham 1995). Consequently most developing countries in recent history have paid greater attention to the promulgation of anti-corruption legislation, regulations and guidelines of various kinds (Doig \& Riley 1998).

In Ghana, the development of anti-corruption legislation was given greater impetus after the return to democratic rule in the late nineties (Mensah et al. 2003). A good number of statutes have been passed to streamline the public sector financial system, amongst other things. One of several anti-corruption laws in Ghana is the Public Procurement Act (Act No. 663 of 2003). The law sets out the administrative and institutional framework for public procurement, stipulates 
tendering procedures and provides for connected purpose (Ghana Government 2003). Coupled with this legislation are manuals on public procurement which provide standards and procedures for the procurement of goods, works and services within the public sector and guidelines on disposal of assets (Ghana Government 2004). Apart from the guidelines issued by the Public Procurement Authority (PPA), administrative support in the form of micro- or departmental policies is fundamental to legislative implementation, operationalisation and enforcement of this legislation. Thus, in the promulgation of all parent legislation, it is usually expected that implementing agencies would craft the needed policies to give effect to the legislation (Coldham 1995; Doig, Watt \& Williams 2007).

The procurement practices of ministries, departments and agencies (MDAs) have been widely researched in Ghana. However, the assets disposal practices of MDAs have not enjoyed equal importance amongst academics and practitioners alike. Literature on assets disposal in the public sector is therefore negligible. Despite the myriad findings in Ghana's Auditor-General Reports on wrongful disposal of state assets, deficient internal controls and the lack of or blatant disregard for policies on stores management and assets disposal, the matter seem not to have been accorded the necessary attention. For example, the Auditor-General's Report on the headquarters of the Ministry of Food and Agriculture indicated that obsolete data processing equipment had been stockpiled for between 2-12 years without being disposed of (Auditor-General 2006). This situation persisted when the Public Procurement Act had clearly provided procedures for the disposal of obsolete assets. Notwithstanding the holding costs incurred as a result of the non-disposal of these items, which is widespread across Ghana (Auditor-General 2009), the value of any subsequent cash inflows from disposal may equally be eroded because of the time value of money.

This research was designed in the light of the above to assess the extent of statutory compliance in assets disposal and the availability of institutional policy support in selected polytechnics in Ghana. The primary aim was to ascertain the level to which disposal of assets in public institutions in Ghana achieve value for money within the context of the Public Procurement Act. This article seeks to:

- ascertain the existence of entity-specific policies and procedures on stores disposal amongst Ghana's polytechnics

- evaluate management's understanding regarding stores disposal as provided for under Act 663 of 2003

- determine the dominant disposal method applied (if any).

The significance of this study is that it is one of the first to examine at the institutional level the specific matter of assets disposal within the context of Ghana's public sector. It will provide contributory evidence regarding the assets disposal practices of the selected institutions with the view to complement contemporary literature on the practical implementation of procurement legislation in Ghana.
Stores management plays a critical role in every organisation, irrespective of the type of entity (government or privately owned) and or the nature of its operations (i.e. services or goods). At the heart of the transformation process lays the very important matter of continuous flow of material inputs and equipment, in the right quantities, quality and at the right time (Stevenson 2007). When materials are readily available in sufficient quantities and in suitable conditions, entities are able to optimise their operations so that plant and labour do not lie idle. However, materials and equipment could become obsolete or unserviceable as a result of long usage or the introduction of new technology, or may simply be procured in quantities that are in excess of entity-specific demand, consequently creating a surplus and thereby rendering their immediate consumption impossible. In such situations a decision has to be made regarding alternative uses to which such stores/materials could be put, including disposal. Disposal of stores is therefore one of the key functions in materials handling or stores management.

Most private-sector organisations have specific policies regulating stores disposal activities whilst others incorporate it under the umbrella of finance and accounting policies. In the context of public-sector entities, legislative enactments and gazetted ministerial guidelines constitute the foundation for material management and stores disposal. For example, Ghana's Public Procurement Act (Act No. 663 of 2003) provides the legal framework for the acquisition and disposal of stores by all public-sector entities in the country. Coupled with this legislation are procurement guidelines published by the PPA, the main body regulating procurement related practices in Ghana, and cabinet and or ministerial directives all aimed at ensuring value for money and protecting the public interest within the public procurement process.

Various reports of the Auditor-General of Ghana have cited a plethora of instances of wrongful disposal of assets, deficient internal controls to deal with stores management, blatant disregard for procedures in public procurement and wilful violations of the Act in activities of most MDAs.

\section{Methods}

This exploratory study attempts to ascertain the extent of compliance with Ghana's Public Procurement Act (Act No. 663 of 2003) in five polytechnics regarding the disposal of unserviceable assets. The central thesis of this article is 'value for money' with a focus on the assets disposal procedures of the selected institutions. These institutions were purposively selected taking into account the number of years in existence and scale of operations. These factors were deemed important as they correlate with procurement activities through use and consequently estimated useful lives of assets. A survey strategy was employed and questionnaires were administered to sampled officers (Table 1).

A non-probability sampling method was adopted in the selection of rectors, vice rectors, registrars, finance officers and internal auditors, whilst a probability sampling method was applied in selecting all other respondents 
TABLE 1: Respondents and response rates.

\begin{tabular}{lccc}
\hline Respondents & $\begin{array}{c}\text { Number } \\
\text { sent }\end{array}$ & $\begin{array}{c}\text { Number } \\
\text { returned }\end{array}$ & $\mathbf{\%}$ \\
\hline Rectors & 5 & 3 & 60 \\
Vice rectors & 5 & 4 & 80 \\
Finance officers and their deputies & 13 & 8 & 62 \\
Registrars and assistant registrars & 20 & 9 & 45 \\
Procurement officers and deputies & 8 & 6 & 75 \\
Internal auditors and deputies & 10 & 4 & 40 \\
Senior accountants & 29 & 15 & 52 \\
Accountants/Heads of Department & 45 & 20 & 44 \\
\hline Total & $\mathbf{1 3 5}$ & $\mathbf{6 9}$ & $\mathbf{5 1}$ \\
\hline
\end{tabular}

in the various groups. The first category merited a nonprobability sampling method because of the finiteness of their population. These classes of respondents were single individuals who occupied unique offices in each polytechnic. A judgmental or purposive sampling technique was applied in the selection of respondents in the first group. The number of participants in this study was 135, comprising rectors, vice rectors, procurement officers, registrars, finance officers, internal auditors and other key senior management staff in the five selected polytechnics, out of an estimated population of 270. In conducting the sampling, due consideration was exercised given the strict composition of the membership of committees clothed with the power to undertake stores disposal as stipulated by procurement legislation.

To obtain primary data for this study, an intervieweradministered questionnaire was distributed to the respondents. The questionnaire contained five-point Likert scale test items together with open-ended questions. The variables measured were grouped into three categories, (1) existence of an institutional stores policy and respondents' knowledge of same, (2) understanding of the Public Procurement Act regarding stores disposal and (3) the methods adopted for stores disposals. The Cronbach alpha $(\alpha)$ was applied as the statistical measure of reliability. The reliability estimates indicated that each test item had an alpha $(\alpha)$ value greater than the mostly recommended magnitude of 0.70 , according to Pallant (2005). The study employed descriptive statistics in the data analysis. A one-way analysis of variance (ANOVA) was also conducted with the aim of determining the level of significant disagreement or otherwise of the respondents on the specific variables measured.

\section{Hypothesis}

Given the plethora of documented violations of public procurement processes and procedures in various AuditorGeneral Reports on public institutions in Ghana, as evidenced in the review of literature, we have put forward and evaluated the following hypothesis with the aim of eliciting evidence regarding the extent to which value for money is achieved in asset disposal activities in polytechnics in Ghana:

- Hypothesis 0: Disposal of assets in public-sector institutions in Ghana does not always achieve value for money.

- Hypothesis 1: Disposal of assets in public-sector institutions in Ghana always achieves value for money.

\section{Discussion of results Biographic information of respondents}

An analysis of respondents' biographic information revealed that the rectors, vice rectors and registrars who responded had been in office for not less than 3 years. All other officers had a minimum tenure of office of 6 years. They have also been involved at times, more than once, in carrying out disposal of assets at their respective institutions. All the rectors have had no less than 7 years' senior management experience in the public or private sector, prior to their joining the polytechnic. The finance officers, internal auditors and procurement officers were either members of professional accountancy bodies, held at least postgraduate degrees or both.

\section{Institutional policy support}

Overall, only two of the five institutions had internal policies or guidelines on disposal of stores. Those institutions with stores policies had not reviewed their policies in the last 5 years. The frequency of application of the policy in stores disposal was also examined (Table 2). Those institutions in which internal disposal policies existed were grouped and analysed separately to determine the extent to which the policies worked. The questions tested the frequency with which the policy was applied in the actual conduct of disposal of assets on the one hand and how responsive the policy is to changes in legislation in terms of how often it is reviewed. The results indicated very low levels of responsiveness. The policies also seemed to exist in name only as they are rarely applied.

\section{Understanding of Ghana's procurement legislation and guidelines}

As a whole, $81.16 \%$ of all respondents understood the legislation together with the guidelines issued by the PPA, whilst more than half of this group, predominantly management staff, clearly understood the legislation. Those who did not understand the legislation seemed not to be directly involved with procurements and disposal, as they were in lower management. Table 3 depicts the levels of understanding of the Public Procurement Act, especially the sections dealing with assets disposal practices by various categories of staff. Half of the accountants/ Heads of Department (HoDs) did not understand Ghana's procurement legislation and the guidelines regarding the disposal of stores, plants and equipment. This could be because most of the HoDs are focused on managing their academic department and may not be directly involved in assets disposal activities.

\section{Results of analysis of variance}

The ANOVA indicated that respondents' institutional policies do not support existing procurement legislation in terms of the degree of responsiveness of the policies, as evidenced 
TABLE 2: Existence of institutional stores disposal policy and its functionality.

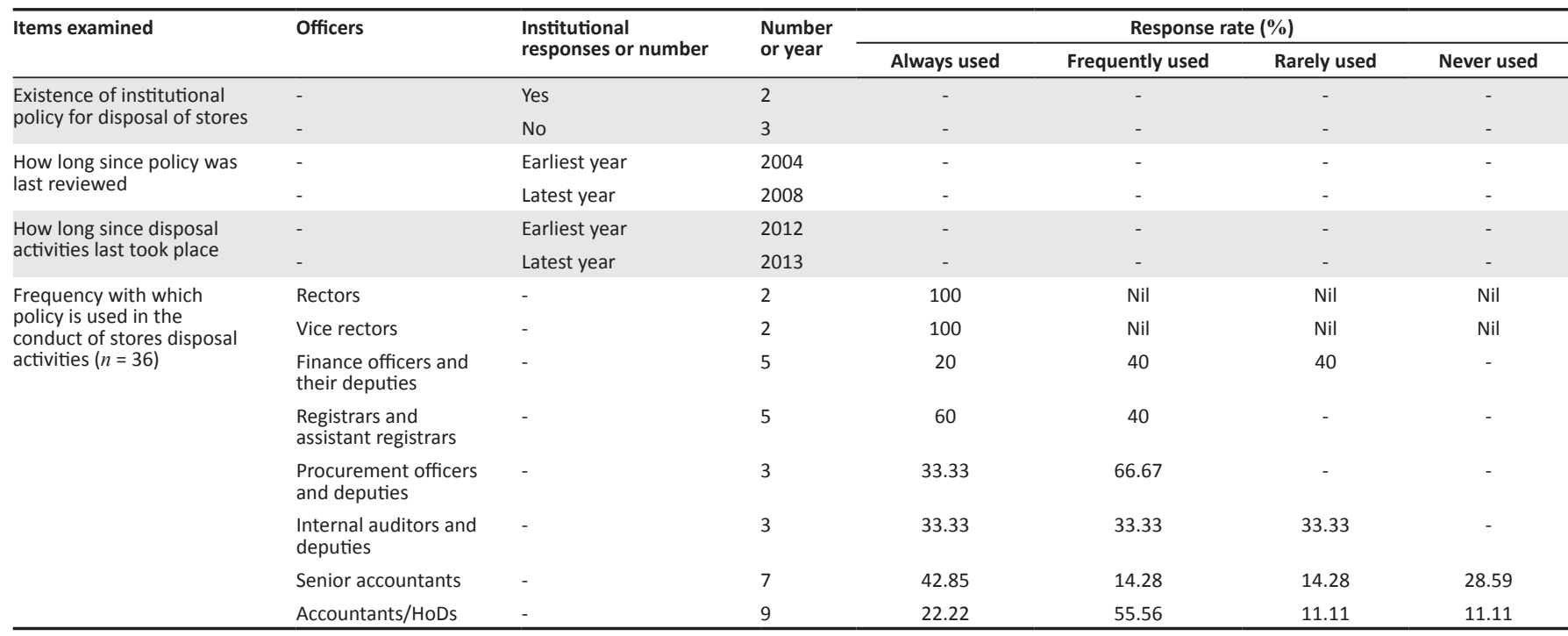

HoDs, Heads of Department.

TABLE 3: Responses regarding understanding of Ghana's procurement legislation and guidelines.

\begin{tabular}{|c|c|c|c|c|c|c|c|}
\hline \multirow[t]{2}{*}{ Management/employees of the polytechnics } & \multicolumn{7}{|c|}{ Levels of understanding of Ghana's procurement legislation and procedures } \\
\hline & Clearly understand & $\%$ & Understand & $\%$ & Do not understand & $\%$ & Total $100 \%$ \\
\hline Rectors & 3 & 100 & 0 & 0 & 0 & 0 & 3 \\
\hline Vice rectors & 3 & 75 & 1 & 15 & 0 & 0 & 4 \\
\hline Finance officers and their deputies & 7 & 88 & 1 & 12 & 0 & 0 & 8 \\
\hline Registrars and assistant registrars & 4 & 44.44 & 4 & 44.44 & 1 & 11.11 & 9 \\
\hline Procurement officers and deputies & 6 & 100 & 0 & 0 & 0 & 0 & 6 \\
\hline Internal auditors and deputies & 2 & 50 & 2 & 50 & 0 & 0 & 4 \\
\hline Senior accountants & 10 & 67 & 3 & 20 & 2 & 13 & 15 \\
\hline Accountants/Heads of Department & 5 & 25 & 5 & 25 & 10 & 50 & 20 \\
\hline$\overline{\text { Total }}$ & 40 & 57.97 & 16 & 23.18 & 13 & 18.85 & 69 \\
\hline
\end{tabular}

in their non-review (Table 4a). In addition, the practical deployment of policies in the conduct of disposal activities was also lacking, even though some policies did exist in a few polytechnics, as shown in Table 2 . These assertions are corroborated by the $p$-values for each of these test items (Table 4a).

Achieving value for money in disposal of assets hinges greatly on the levels of procedural propriety in disposal activities. To this extent we examined management's levels of understanding of the Public Procurement Act, as it influences the levels of compliance and ultimately value for money. The results of the ANOVA on management and other staff's levels of understanding indicate that there is a significant difference regarding the reporting responsibility of the Board of Survey, as indicated in the $p$-value $(0.0640$ $>0.0500$ ) (Table $4 \mathrm{~b}$ ). The remaining results indicate no significant levels of difference at $5 \%$ on all the test items regarding the procedure for disposals as stipulated in the Act.

On the question of whether value for money was achieved in the conduct of actual disposals, respondents' opinions regarding the procedure for assets disposal as stipulated in the Public Procurement Act was examined. These were employed based on the null hypothesis of this study. There was no significant disagreement over the existing procedure except for the issue of getting experts to be a part of the board of survey (BoS). The $p$-value (0.05) for that test item exactly equals the chosen level of significance (Table 4c). Thus, this may require further examination before any reasonable conclusions can be drawn.

\section{Evaluation of hypothesis}

The hypothesis was evaluated using Tukeys- $b$, assumed equality of means in a one-way ANOVA:

- Hypothesis $\mathbf{0}\left(\mathbf{H}_{0}\right)$ : Disposal of assets in public sector institutions in Ghana does not always achieve value for money.

This hypothesis sought to evaluate by comparing the perceptions of polytechnics' management and staff regarding the level of value for money achieved in the course of actual disposals of assets. The test of equality of means showed no significant difference in all the areas examined at the $5 \%$ level of confidence as all $p$-values were less than 0.005 . The implication of this is that the null hypothesis is not disproved. Thus, the null hypothesis is accepted whilst the alternate hypothesis is rejected. 
TABLE 4a: Institutional policy support.

\begin{tabular}{|c|c|c|c|c|c|c|}
\hline Tested item & Description & Sum of squares & Degree of freedom & Mean square & $F$-statistic & $P$-value \\
\hline \multirow[t]{3}{*}{ Policy exists } & Between groups & 0.040 & 2 & 0.020 & 0.246 & 0.001 \\
\hline & Within groups & 2.754 & 34 & 0.081 & - & - \\
\hline & Total & 2.794 & 36 & - & - & - \\
\hline \multirow[t]{3}{*}{ Has policy been reviewed? } & Between groups & 0 & 2 & 0 & - & - \\
\hline & Within groups & 0 & 34 & 0 & - & - \\
\hline & Total & 0 & 36 & - & - & - \\
\hline \multirow{2}{*}{$\begin{array}{l}\text { Frequency with which institution's } \\
\text { policy is used }\end{array}$} & Within groups & 26.792 & 34 & 0.788 & - & - \\
\hline & Total & 27.554 & 36 & - & - & - \\
\hline
\end{tabular}

TABLE 4b: Levels of understanding of Ghana's procurement legislation and procedures.

\begin{tabular}{|c|c|c|c|c|c|c|}
\hline Tested item & Description & Sum of squares & Degree of freedom & Mean square & $F$-statistic & $P$-value \\
\hline \multirow[t]{3}{*}{ A BoS shall be constituted } & Between groups & 0.326 & 2 & 0.163 & 0.260 & 0.0001 \\
\hline & Within groups & 41.942 & 67 & 0.626 & - & - \\
\hline & Total & 42.268 & 69 & - & - & - \\
\hline \multirow{3}{*}{$\begin{array}{l}\text { Membership of BoS shall include } \\
\text { all Heads of Departments with } \\
\text { unserviceable items }\end{array}$} & Between groups & 2.540 & 2 & 1.270 & 0.739 & 0.0002 \\
\hline & Within groups & 115.039 & 67 & 1.717 & - & - \\
\hline & Total & 117.579 & 69 & - & - & - \\
\hline \multirow{3}{*}{$\begin{array}{l}\text { BoS always evaluates and submit } \\
\text { report }\end{array}$} & Between groups & 2.040 & 2 & 1.020 & 1.030 & 0.0000 \\
\hline & Within groups & 66.330 & 67 & 0.990 & - & - \\
\hline & Total & 68.370 & 69 & - & - & - \\
\hline \multirow[t]{3}{*}{ BoS report is approved by the Rector } & Between groups & 1.714 & 2 & 0.857 & 0.493 & 0.064 \\
\hline & Within groups & 24.388 & 67 & 0.364 & - & - \\
\hline & Total & 26.102 & 69 & - & - & - \\
\hline \multirow{2}{*}{$\begin{array}{l}\text { BoS report is approved by head of } \\
\text { entity Chairman of council }\end{array}$} & Between groups & 0.256 & 2 & 0.128 & 0.119 & 0 \\
\hline & Within groups & 71.489 & 67 & 1.067 & - & - \\
\hline
\end{tabular}

BoS, Board of Survey.

TABLE 4c: Perception of value for money in stores disposal.

\begin{tabular}{|c|c|c|c|c|c|c|}
\hline Tested item & Description & Sum of squares & Degree of freedom & Mean square & $F$-statistic & $P$-value \\
\hline \multirow{3}{*}{$\begin{array}{l}\text { It is always difficult to determine fair } \\
\text { values of items to be disposed of }\end{array}$} & Between groups & 0.262 & 2 & 0.131 & 0.135 & 0 \\
\hline & Within groups & 64.990 & 67 & 0.970 & - & - \\
\hline & Total & 65.252 & 69 & - & - & - \\
\hline \multirow{3}{*}{$\begin{array}{l}\text { It is always difficult to place experts } \\
\text { on the BoS }\end{array}$} & Between groups & 0.040 & 2 & 0.020 & 0.0116 & 0.0050 \\
\hline & Within groups & 115.039 & 67 & 1.717 & - & - \\
\hline & Total & 115.079 & 69 & - & - & - \\
\hline \multirow{3}{*}{$\begin{array}{l}\text { This part of the law is expensive in } \\
\text { terms of cost }\end{array}$} & Between groups & 1.944 & 2 & 0.972 & 1.119 & 0.0010 \\
\hline & Within groups & 58.223 & 67 & 0.869 & - & - \\
\hline & Total & 60.167 & 69 & - & - & - \\
\hline \multirow{3}{*}{$\begin{array}{l}\text { The procedures in the law are } \\
\text { laborious and time wasting }\end{array}$} & Between groups & 1.000 & 2 & 0.500 & 0.379 & 0 \\
\hline & Within groups & 88.306 & 67 & 1.318 & - & - \\
\hline & Total & 89.306 & 69 & - & - & - \\
\hline \multirow[t]{3}{*}{ Employees always front for outsiders } & Between groups & 4.190 & 2 & 2.095 & 2.658 & 0.0040 \\
\hline & Within groups & 52.796 & 67 & 0.788 & - & - \\
\hline & Total & 56.986 & 69 & - & - & - \\
\hline \multirow{3}{*}{$\begin{array}{l}\text { There is always political interest in the } \\
\text { items }\end{array}$} & Between groups & 2.444 & 2 & 1.222 & 3.432 & 0.0020 \\
\hline & Within groups & 23.852 & 67 & 0.356 & - & - \\
\hline & Total & 26.296 & 69 & - & - & - \\
\hline \multirow{3}{*}{$\begin{array}{l}\text { There is always conflict of interest from } \\
\text { BoS members }\end{array}$} & Between groups & 3.468 & 2 & 1.734 & 1.281 & 0 \\
\hline & Within groups & 90.718 & 67 & 1.354 & - & - \\
\hline & Total & 94.186 & 69 & - & - & - \\
\hline \multirow{3}{*}{$\begin{array}{l}\text { There is always interest from members } \\
\text { of the governing council }\end{array}$} & Between groups & 3.526 & 2 & 1.763 & 2.857 & 0 \\
\hline & Within groups & 41.339 & 67 & 0.617 & - & - \\
\hline & Total & 44.865 & 69 & - & - & - \\
\hline \multirow{3}{*}{$\begin{array}{l}\text { There is always interest from } \\
\text { management }\end{array}$} & Between groups & 3.468 & 2 & 1.734 & 2.030 & 0.0012 \\
\hline & Within groups & 57.218 & 67 & 0.854 & - & - \\
\hline & Total & 60.686 & 69 & - & - & - \\
\hline \multirow{3}{*}{$\begin{array}{l}\text { The entire process does not often } \\
\text { achieve value for money }\end{array}$} & Between groups & 3.944 & 2 & 1.972 & 3.905 & 0.0001 \\
\hline & Within groups & 33.835 & 67 & 0.505 & - & - \\
\hline & Total & 37.779 & 69 & - & - & - \\
\hline
\end{tabular}

BoS, Board of Survey. 


\section{Conclusion}

Ghana's Public Procurement Act (Act No. 663 of 2003) was enacted, amongst other things, to streamline, regulate and control public procurement activities generally and to facilitate the disposal and efficient management of obsolete and unserviceable items within the public sector. It was also expected to foster competition, efficiency, transparency and accountability with the view to achieving value for money.

One important conclusion from this study is that the majority of Ghana's polytechnics do not have assets disposal policies in place to operationalise the Public Procurement Act. Therefore all public procurement stakeholders - the PPA, rectors and their management staff - have to effectively collaborate to bring about assets disposal policies in these institutions which will not only operationalise legislation but also ensure that value is achieved in every public procurement transaction.

\section{Limitations or application of the findings}

The findings of this study may have some limitations. Firstly, the number and categories of public sector institutions selected are limited. The results may therefore not be completely representative of all the polytechnics in Ghana. This weakness notwithstanding, the study seems to be a novel contribution to the 'last mile' activity in the procurement and use of assets by public-sector institutions in Ghana. Secondly, the unavailability of literature in this specific area was constraining. We thus hope that this article will serve as a launch pad for further study.

\section{Suggested areas for future research}

It is suggested that future studies in this area should be conducted using a larger sample size and including other Departments and Metropolitan, Municipal and District Assemblies (MMDAs). In addition, future studies could be conducted into the use and effectiveness of public auction as a tool for assets disposal within the public sector.

\section{Acknowledgements Competing interests}

The authors declare that they have no financial or personal relationships which may have inappropriately influenced them in writing this article.

\section{Authors' contributions}

O.A. (Bolgatanga Polytechnic) generated the idea for the article and reviewed and synthesised relevant literature for the write-up. C.J.A. (Bolgatanga Polytechnic) was responsible for data analysis and interpretation of results and J.D.N. (Wa Polytechnic) for editing the manuscript.

\section{References}

Alberto, A. \& Tella, D.R., 1997, 'The new economics of corruption: A survey and some new results', Political Studies 45, 497-498.

Auditor-General, 2006, Procurement audit report of the Auditor General on the Ministry of Food and Agriculture headquarters, Assembly Press, Accra.

Auditor-General, 2009, Procurement audit report of the Auditor General on the Ministry of Finance and Economic Planning, Assembly Press, Accra.

Coldham, S., 1995, 'Legal responses to state corruption in Commonwealth Africa', Journal of African Law 39(2), 115-126. http://dx.doi.org/10.1017/ S0021855300006276

Doig, A. \& Riley, S., 1998, 'Corruption and anti-corruption strategies: Issues and case studies from developing countries', in United Nations Development Programme (ed.), Corruption and integrity improvement initiatives in developing countries, pp. 45-62, UNDP, New York.

Doig, A., Watt, D. \& Williams, R., 2007, 'Why do developing country anti-corruption commissions fail to deal with corruption? Understanding the three dilemmas of organisational development, performance expectation, and donor and government cycles', Public Administration and Development 27(3), 251-259. http://dx.doi.org/10.1002/pad.452

Ghana Government, 2003, Public Procurement Act, Act 663 2003, Assembly Press, Accra.

Ghana Government, 2004, Manual - Public Procurement Act 2003 (Act 663), Assembly Press, Accra.

Hutter, J. \& Shar, A., 2000, Anti-corruption policies and programs: A framework for evaluation, Policy Research Working Paper 2501, World Bank, Washington, DC.

Mensah, S., Aboagye, K., Addo, E. \& Buatsi, S., 2003, Corporate governance and corruption in Ghana: Empirical findings and policy implications, African Capital Markets Forum, Johannesburg.

Pallant, J., 2005, SPSS survival manual: A step by step guide to data analysis using SPSS for Windows, Open University Press, Maidenhead.

Persson, A., Rothstein, B. \& Teorell, J., 2010, The failure of anti-corruption policies: A theoretical mischaracterization of the problem, QoG Working Paper Series 19, Gothenburg.

Stevenson, W., 2007, Operations Management, McGraw-Hill/Irwin, Boston.

World Health Organization (WHO), 1999, Guidelines for the safe disposal of unwanted pharmaceuticals in and after emergencies: Interagency guidelines, WHO, Geneva. 